\title{
Temporal and spatial variation in the Nazaré Canyon (Western Iberian margin): Inter-annual and canyon heterogeneity effects on meiofauna biomass and diversity
}

\author{
Sofia P. Ramalho a,d,*, Helena Adão ${ }^{a}$, Konstadinos Kiriakoulakis ${ }^{b}$, George A. Wolff ${ }^{c}$, \\ Ann Vanreusel ${ }^{\mathrm{d}}$, Jeroen Ingels ${ }^{\mathrm{d}, e}$ \\ a Évora University, Biology Department c/o CO-CIEMAR, Center of Oceanography, NemaLab, Apartado 94, 7002-554 Évora, Portugal \\ ${ }^{\mathrm{b}}$ School of Natural Sciences and Psychology, Liverpool John Moores University, James Parsons, Byrom Street, Liverpool, Merseyside L33AF, UK \\ ' School of Environmental Sciences, University of Liverpool, 4 Brownlow Street, Liverpool L693GP, UK \\ ${ }^{d}$ Ghent University, Marine Biology Research Group, Krijgslaan 281 S8, 9000 Ghent, Belgium \\ e Plymouth Marine Laboratory, Prospect Place, The Hoe, Plymouth PL1 3DH, UK
}

\section{A R T I C L E I N F O}

\section{Article history:}

Received 13 May 2013

Received in revised form

25 September 2013

Accepted 27 September 2013

Available online 10 October 2013

\section{Keywords:}

Meiofauna

Nematodes

Community structure

Biomass

Environmental conditions

Inter-annual variation

Submarine canyon

Nazaré

NE Atlantic

\begin{abstract}
A B S T R A C T
The Nazaré Canyon on the Portuguese Margin (NE Atlantic) was sampled during spring-summer for three consecutive years (2005-2007), permitting the first inter-annual study of the meiofaunal communities at the Iberian Margin at two abyssal depths $(\sim 3500 \mathrm{~m}$ and $\sim 4400 \mathrm{~m})$. Using new and already published data, the meiofauna standing stocks (abundance and biomass) and nematode structural and functional diversity were investigated in relation to the sediment biogeochemistry (e.g. organic carbon, nitrogen, chlorophyll $a$, phaeopigments) and grain size. A conspicuous increase in sand content from 2005 to 2006 and decrease of phytodetritus at both sites, suggested the occurrence of one or more physical disturbance events. Nematode standing stocks and trophic diversity decreased after these events, seemingly followed by a recovery/recolonisation period in 2007, which was strongly correlated with an increase in the quantity and bioavailability of phytodetrital organic matter supplied. Changes in meiofauna assemblages, however, also differed between stations, likely because of the contrasting hydrodynamic and food supply conditions. Higher meiofauna and nematode abundances, biomass and trophic complexity were found at the shallowest canyon station, where the quantity, quality and bioavailability of food material were higher than at the deeper site. The present results suggest that even though inter-annual variations in the sedimentary environment can regulate the meiofauna in the abyssal Nazaré Canyon, heterogeneity between sampling locations in the canyon were more pronounced.
\end{abstract}

(c) 2013 Elsevier Ltd. All rights reserved.

\section{Introduction}

In contrast to earlier ideas of the deep sea as a remote faunal desert, we now know that it harbours diverse assemblages of animals and protists. Organisms inhabiting this environment are subjected to variable regulating disturbance and seasonal/episodic productivity regimes related to upper water-column processes (Gage and Tyler, 1991). Understanding benthic community responses to such events allows insights into deep-sea diversity and dynamics (Gage and Tyler, 1991; Gooday, 2002; Billett et al., 2010). There is evidence that smaller

\footnotetext{
* Corresponding author at: Évora University, Biology Department c/o CO-CIEMAR Center of Oceanography NemaLab, Apartado 94, 7002-554 Évora, Portugal. Tel.: + 351266760 881; fax: +351266760912.

E-mail addresses: sofia.pinto.ramalho@gmail.com (S.P. Ramalho), hadao@uevora.pt (H. Adão), K.Kiriakoulakis@ljmu.ac.uk (K. Kiriakoulakis), wolff@liverpool.ac.uk (G.A. Wolff), ann.vanreusel@ugent.be (A. Vanreusel), jein@pml.ac.uk (J. Ingels).
}

benthic organisms tend to respond quickly to pulses of organic-rich detritus, with increases in standing stocks and enhanced metabolic responses (Gooday, 2002; Guidi-Guilvard et al., 2009). Nevertheless we are still confronted with a lack of knowledge on the scales (temporal and spatial) at which different processes regulate deep-sea communities, including conclusive insights into the cause-effect relationships (Glover et al., 2010; Ingels and Vanreusel, 2013). In addition, for certain relatively homogeneous deep-sea habitats it is possible to roughly predict faunal response to, for instance, yearly peaks in organic matter (OM) fluxes (Gooday, 2002), while for other, more complex and dynamic habitats, patterns are more challenging to investigate. This is particularly the case for submarine canyons, where different regulating processes and heterogeneous environmental conditions act in concert, in time and space, to structure faunal communities (e.g. Bianchelli et al., 2008; Ingels and Vanreusel, 2013; McClain and Barry, 2010).

Submarine canyons are pervasive, large-scale geological features that cut the continental shelf and slope, and form a direct 